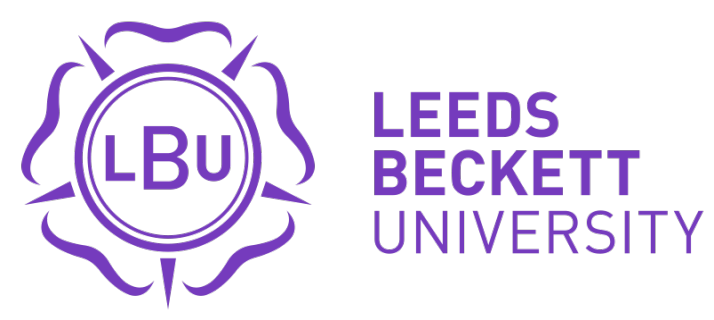

Citation:

Ajayi, SO and Oyedele, LO and Ilori, OM (2019) Changing Significance of Embodied Energy: A comparative study of material specifications and building energy sources. Journal of Building Engineering, 23. pp. 324-333. ISSN 2352-7102 DOI: https://doi.org/10.1016/j.jobe.2019.02.008

Link to Leeds Beckett Repository record:

https://eprints.leedsbeckett.ac.uk/id/eprint/5689/

Document Version:

Article (Accepted Version)

The aim of the Leeds Beckett Repository is to provide open access to our research, as required by funder policies and permitted by publishers and copyright law.

The Leeds Beckett repository holds a wide range of publications, each of which has been checked for copyright and the relevant embargo period has been applied by the Research Services team.

We operate on a standard take-down policy. If you are the author or publisher of an output and you would like it removed from the repository, please contact us and we will investigate on a case-by-case basis.

Each thesis in the repository has been cleared where necessary by the author for third party copyright. If you would like a thesis to be removed from the repository or believe there is an issue with copyright, please contact us on openaccess@leedsbeckett.ac.uk and we will investigate on a case-by-case basis. 


\title{
Changing Significance of Embodied Energy: A comparative study of material specifications and building energy sources
}

Ajayi, S. O.; Oyedele, L. O.; Ilori, O. M.

\begin{abstract}
Despite the increasing significance of embodied impacts of buildings, efforts to reduce their environmental footprints have been concentrated on the operational impacts of buildings. This study investigates the changing significance of embodied carbon over the entire life cycle of whole buildings. A case study of an office building was modelled with Revit, and sensitivity analyses of the modelled building were performed by varying the material specification and energy use pattern for seven other typologies. Using Revit, BIMWASTE tool, ATHENA Impact Estimator and Green Building Studio, comparative life-cycle analyses were carried out for the eight building typologies.
\end{abstract}

The study suggests that notwithstanding the enormous impacts of the operational stage on lifecycle carbon of fossil fuel-based buildings, embodied impacts could vary between 8.4 and $22.3 \%$. A key determinant of the proportional impacts of embodied energy is the nature of materials used for building construction. Similarly, embodied impacts of buildings become more significant and could contribute up to $60 \%$ of their life cycle impacts as they become more energy-efficient during their operational stage. As the study confirms the varying significance of embodied energy as construction materials and energy use patterns change, it implies the need for policy measures based on a whole life assessment methodology, instead of the usual ways of giving sole importance to the operational impacts of buildings. With buildings becoming more energy-efficient during their operational stage, there is an urgent need for an increased focus on the embodied impacts of buildings, especially as renewable energy resources are becoming widely adopted.

Keywords: Building energy analysis; embodied emission; operational emission; renewable energy; LCA. 


\subsection{Introduction}

The construction sector has become a key target for reducing global carbon footprint, as the industry accounts for about half of energy consumption, a third of global emission and about $50 \%$ of materials consumption (Pearce and Ahn, 2013; Baek et al., 2013). According to Li (2006), reduction of the environmental burden of the building industry is essential to achieving the sustainable development goals. Due to this, there has been an increasing stringency of building regulations, especially in developed nations. In the UK for instance, part L of the building regulation has been consistently revised to drive the government's commitment to reduce the environmental impacts of buildings. Similarly, building performance, green buildings, eco-labelling, life cycle impacts, sustainable building and environmental impacts, among others, are some of the concepts that have changed, and are continuously evolving, the teaching and professional practices within the built environment (Ding, 2008; Ajayi et al., 2015; Ortiz et al., 2009).

The governments and other concerned bodies across the globe have introduced the concept of sustainable design appraisal frameworks, which are being used to engender sustainable design and construction of built infrastructures (Kajikawa et al., 2011). Examples of such appraisal tools include the Building Research Establishment Environmental Assessment Method (BREEAM), Leadership in Energy and Environmental Design (LEED), the Comprehensive Assessment System for Built Environment Efficacy (CASBEE), Comprehensive Environmental Performance Assessment Scheme (CEPAS) and the Passivhaus standard, among others (Cole, 2005; Poveda and Lipsett, 2011). While some of the appraisal systems consider the whole life impacts of buildings, others consider only operational impacts during the use stage, leaving out or giving less consideration to other critical stages of buildings' life cycle (Kubba, 2012).

Apart from operational impact of buildings, another impact that could significantly reduce the carbon footprint of buildings is the embodied impacts, which combines energy used for raw materials extraction and transportation, raw materials processing, as well as the energy used for building construction and maintenance over its entire lifecycle (Fay et al., 2000; Bribián et al., 2009). According to Basbagill et al. (2013), the increasing energy efficiency of buildings during its operational stage requires that other stages in its life cycle process should be addressed. While the significance of the embodied energy and impact is becoming recognised, 
it has received less attention in comparison to the operational impacts of buildings (Tavares et al. 2019). The aim of this study is to investigate the changing significance of embodied carbon over the entire life cycle of whole buildings.

The study fulfils its goals through the following objectives:

- To investigate the impacts of materials specifications on embodied and whole life impacts of buildings

- To understand the extent to which passive design and renewable technologies influence embodied impacts of buildings

- To evaluate the changing significance of embodied impacts as buildings become more or less energy efficient

A thorough methodology for assessing the importance of the different stages of building lifecycle, and for understanding its actual environmental impacts is the cradle-to-grave/cradle approach (Khasreen et al., 2009). The concept of Lifecycle Assessment (LCA), which was traditionally applicable to materials, products and components is now being used for evaluating whole life performance of buildings. Using the ISO14040 framework, this study adopts LCA as its methodological framework. A case study of an office building was modelled with Revit, and sensitivity analyses were carried out by varying the building materials and sources of energy for building operation. The global warming potentials of each typology were then compared to evaluate how the embodied impacts of the building change for each typology.

As a means of providing theoretical insights for the study, the next section provides a review of extant literature on the concept of whole building LCA. This is followed by the methodological framework and description of the case study used for the life cycle analysis. Comparative analysis and findings are then discussed before culminating the study with a conclusion and implications for practice. The result of this study provides insights into the changing significance of embodied impacts as materials and energy sources change.

\subsection{Embodied Impacts of Buildings}

Embodied impacts of a product describe the energy consumed by all the processes that are associated with the mining/extraction of natural resources for materials production, energy used for its transportation, manufacturing and ultimate production of the final product (Hammond and Jones, 2008). When the concept of embodied energy is used for a whole 
building, it encompasses energy involved in the building construction processes in addition to the embodied energy of its construction materials (Khasreen et al., 2009). As such, a whole life impact of a building could be expressed in terms of its embodied impacts, operational impacts and end of life impacts. Meanwhile, studies on embodied impacts of buildings suggest that impact associated with raw materials extraction and subsequent production of the materials account for the highest proportion of embodied impacts of buildings, and it may account for the highest whole life cycle when a building is energy-efficient during the operational stage (Utama et al., 2012). The construction and the demolition stages contribute the least impacts when considering the overall lifecycle impacts of all buildings, irrespective of whether it is powered by fossil fuel or renewable resources (Wang et al., 2011; Utama et al., 2012).

In a break from the increasing concentration of studies on operational impacts of buildings, Chang et al. (2011) quantified the embodied energy of construction projects on energy, environment and society. The study suggests that embodied impacts of a building could be between $25-30 \%$ of the whole life impacts. Kofoworola and Gheewala (2009) also investigated the life cycle impacts of a typical office building in Thailand. The study confirms that notwithstanding the huge proportional contribution of operational impacts over the entire life cycle of buildings, the impacts of embodied energy is not negligible as it can be up to $15 \%$ of the operational impacts. Although these sets of studies could suggest the proportional significance of embodied impacts of buildings, it is difficult to determine the factors contributing to these proportions especially as they were based on a single case study of buildings. Understanding the key determinants of embodied and operational impacts would require sensitivity and comparative analyses of different design scenario (Ceranic, 2013; Azhar et al., 2008).

Based on the analyses carried out using different climatic regions, Ramesh et al. (2012) suggest that climate region could account for a variation of $10 \%-30 \%$ of energy use over buildings lifecycle. Nonetheless, their study shows that notwithstanding the climatic condition and the building materials, the operational stage of building accounts for the most significant proportion of lifecycle impacts. This was also corroborated by a multi-country study by Sartori and Hestnes (2007), which suggests that notwithstanding the climatic condition, there is a linear relationship between the operational and total energy consumption. As building materials vary across different climatic zones and geographical areas, the percentage contribution of the different stages of the building lifecycles also vary. According to Hamilton-MacLaren et al. 
(2009), Basbagill et al. (2013), Ajayi et al. (2016), and Webster (2018), the proportion of lifecycle impacts contributed by the embodied energy could vary significantly depending on how the buildings are operated.

Wang et al. (2011) carried out a life cycle assessment of buildings using Ecotect and BIM model through sensitivity analyses of different design configurations. The study demonstrated how design changes and alternative design parameters could have significant impacts on different life cycle stages of buildings, suggesting that percentage contribution of embodied and operational impacts could be affected by various design and construction parameters. A similar study by Ajayi et al. (2015) involved a sensitivity analyses of a school building, and the study suggests that different design specification would have impacts on whole life carbon emissions of buildings. While these studies pointed out the significance of the material change and design parameters on the whole life impacts and the embodied energy of buildings, they failed to point out whether increasing energy efficiency could affect the proportional significance of embodied impacts over the entire lifecycle of buildings. This is albeit the claim that energy use pattern and low impact building design is likely to increase the embodied impacts of buildings (Optis and Wild, 2009).

While the operational impacts of building accounts for the largest lifecycle impacts of conventional buildings, with a range of between 60-90\% across studies (Zhan et al., 2018; Soares et al., 2017), the overall proportion depends of building use types as well as the number of years considered for the study (Optis and Wild, 2009). On the other hand, when a building is self-sufficient or largely based on renewable energy, the embodied impacts become very significant. With buildings becoming more energy efficient during their use phase, as primarily driven by economic benefits of living sustainably and the increasing stringency of legislative measures, more needs to be done to ascertain and reduce the embodied impacts of buildings. This is expected to be an important consideration for building regulations and sustainable design appraisal systems such as BREAAM and LEED. 


\subsection{Methodology}

This study aims to evaluate how embodied impacts of buildings change with different materials specification and energy use pattern. The study adopts the ISO14040 framework for life cycle analyses, and a case study of an office building was modelled to carry out sensitivity analyses of materials specifications and energy use patterns. This section describes the methodological approach for the study as depicted in Figure 1. A combination of tools was used; this includes the following:

Revit: A BIM modelling and visualisation tool through which the case study model was developed. It also provides an opportunity for materials take-off for different building components such as walls, floors, and so on, thereby providing the input inventory for the LCA tool. Revit has been used for the study as it is one of the most widely used BIM-based design tools for LCA (Nizam et al., 2018), and it allows scenario analysis of the operational energy through its integrated platform for energy analysis.

Green Building Studio: Formerly a standalone tool, the inbuilt energy analysis tool for Revit is used for evaluating the operational impacts of buildings.

BIMWASTE Tool: A plug-in tool for predicting and minimising waste generated from construction activities. It helped in mining and aggregating the volume of each material used in the building for accurate input into the Lifecycle Analysis tool.

ATHENA Impact Estimator (IE): Impact Estimator is an LCA tool that is underpinned by the international standard for carrying out LCA of whole buildings. It helps to convert the materials used for the building construction, energy used for operation and the predicted energy associated with construction to various impact categories (ATHENA, 2013). The IE receives inventory of materials and energy and then convert them into various impact categories such as Global Warming Potential, Acidification, and so on. With this, the IE could help designers to trade between different design options for environmental sustainability at the early stage. In addition to being freely available, the LCA tool was specifically chosen for the study as it requires minimal input (Basbagill et al. 2013). Thus, the study demonstrates a simpler way of carrying out a sensitivity analysis of different design options. 


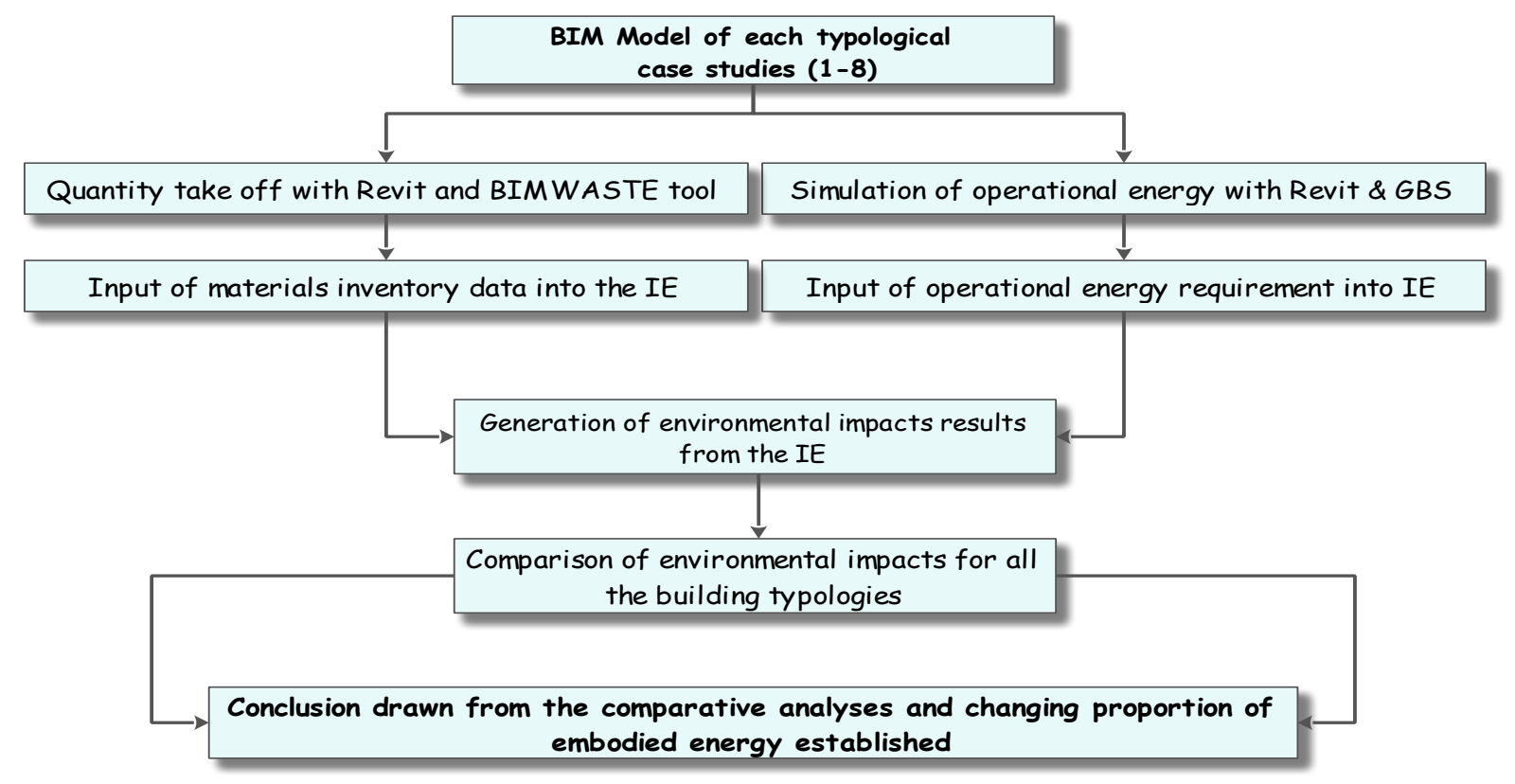

Figure 1: Methodological flow for the study

\subsection{LCA Methodological Framework}

LCA, through the ISO14040 framework, consists of goal and scope definition, inventory analysis, impact assessment and implementation stages (Khasreen et al., 2009). The goal of this study is to compare the whole life impacts of a modelled case study and its sensitivity analyses. The building was modelled to BIM level 2 standard, using Revit.

As a data collection and calculation phase, the inventory analysis of the modelled building was computed through three software tools. Materials take-off was initially taken through Revit, and a waste management tool called BIMWASTE was used for accurate mining and aggregation of all materials used in the design. Although the BIMWASTE was originally designed for waste prediction, it is equally capable of calculating the volume of materials that are associated with BIM-based design. The screenshot of materials extraction from the BIMWASTE tool is as shown in Figure 2. The volume of materials and associated operational energy are then inputted into the IE. 


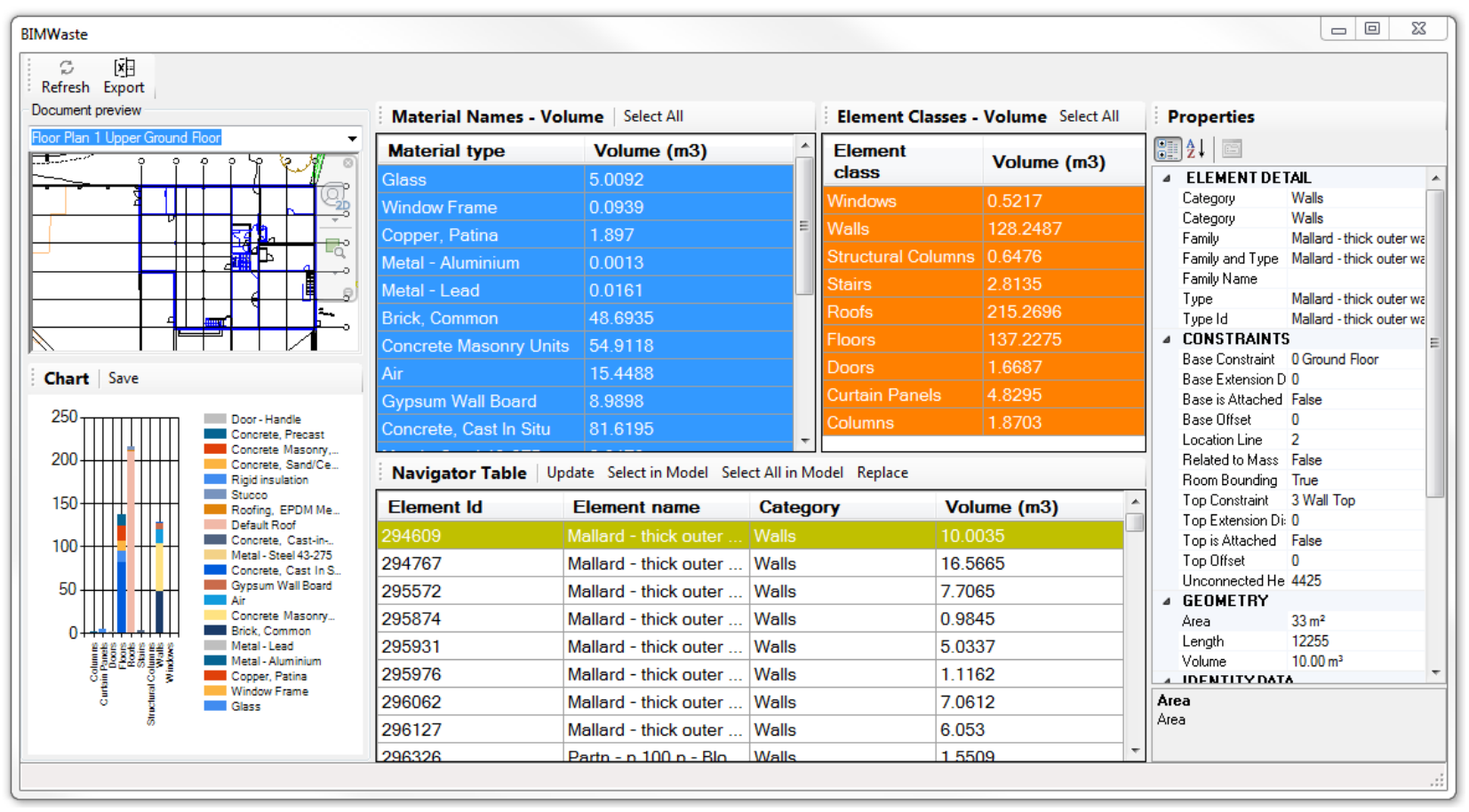

Figure 2: Screenshot of materials inventory from BIMWASTE tool

The inventory of energy required for building operation is calculated through Revit energy analysis tool and Autodesk Green Building Studio (GBS). The results from the GBS are then inputted into the IE, which in turns calculate the whole life impacts of each design into different impacts categories, such as global warming potential, acidification and Ozone depletion, among others. The Impact Estimator considers the whole life impacts of the building, including the extraction of the raw material, transportation of the raw materials, processing and the actual material production, on-site construction, building maintenance and repair, and associated end of life effects based on the bill of materials specified by the user. The impact category considered in the study is the global warming potential, which is measured in $\mathrm{Kg}$ of carbon that would be produced by the building throughout its lifecycle. This is mainly as the global warming potential is considered to be the most significant of all the impact categories (Hamilton et al., 2007).

To align with the provision of 30 years available in GBS, which was used for evaluating operational impacts of the buildings, and in line with Ghattas et al. (2013), a period of 30 years was used for the LCA analysis of the building typologies. As a way of interpreting the results in line with the goal of the study, the global warming potentials were compared across all the typologies used for the study. Figure 3 depicts the system boundary for the study. 


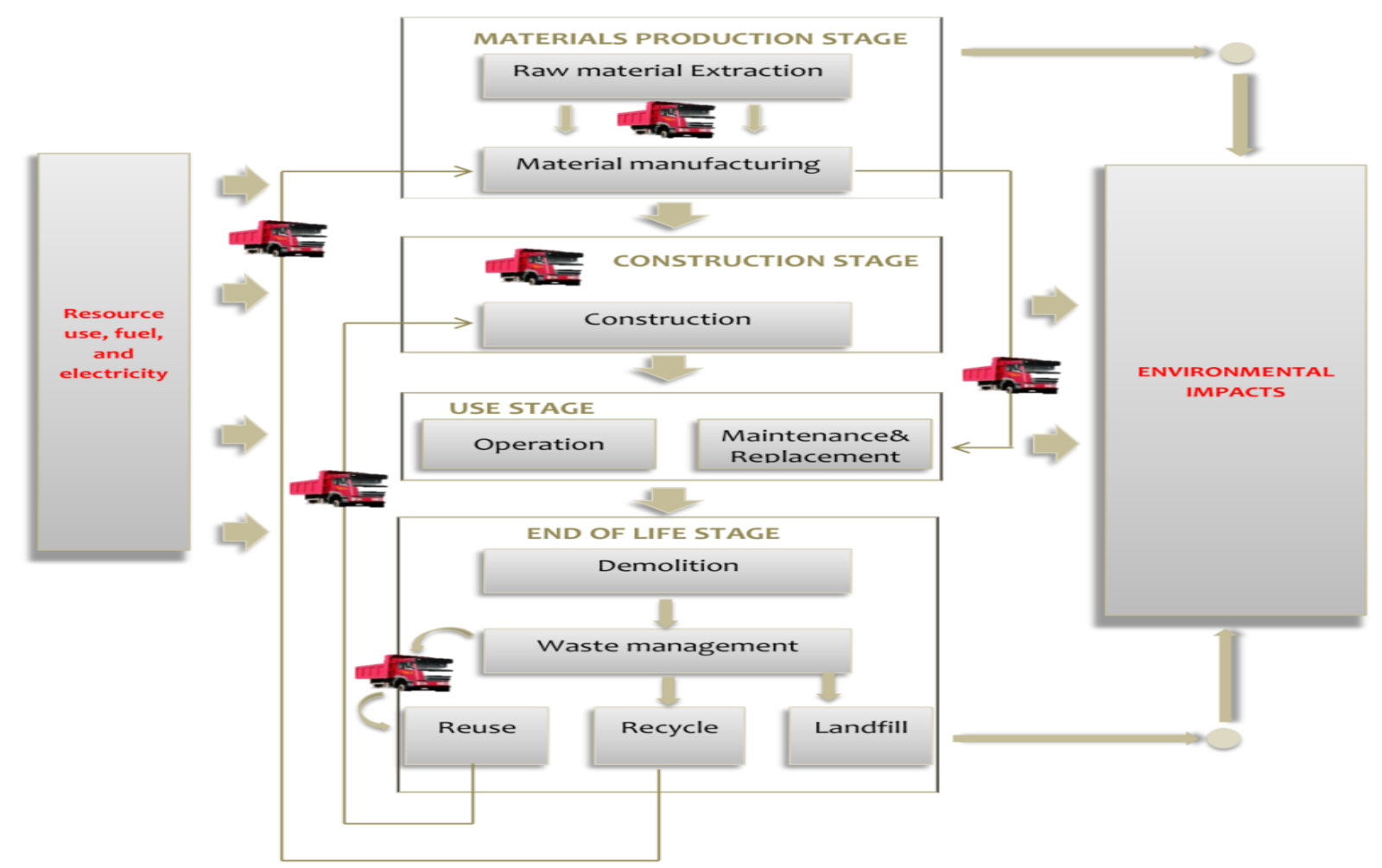

Figure 3: System boundary used for the study

\subsection{Case study Modelling and Sensitivity Analyses}

A case study of an office block was modelled to determine the impacts of embodied energy over the entire life cycle of buildings. Table 1 gives an overview of the case study model.

\begin{tabular}{|l|l|}
\hline \multicolumn{2}{|c|}{ Table 1: Design characteristics of the case study } \\
\hline Building type: Office block & Number of floors: 3 \\
Ground Floor area: $492 \mathrm{~m}^{2}$ & First-floor area: $351 \mathrm{~m}^{2}$ \\
Second-floor area: $351 \mathrm{~m}^{2}$ & Second-floor roof area: $402 \mathrm{~m}^{2}$ \\
Lighting control: All manual & Low-level roof: $168 \mathrm{~m}^{2}$ \\
\hline
\end{tabular}

Sensitivity analyses were also carried out on the building by varying the building materials type, design standards and energy use pattern of the case study. The original model was taken as Typology 1, and the building is based on the use of electricity and gas for its operation. The typology 1 was constructed as a traditional British brick and block building. As a way of facilitating model comparison through sensitivity analysis, materials specifications were varied for other three building typologies. This resulted in typologies 2, 3 and 4 . The three typologies were timber-framed, insulated concrete form (ICF) and steel framed structure respectively. Table 2 presents the materials specifications for the eight typologies. 
Table 2: Materials and energy use variation across the typologies

\begin{tabular}{|c|c|}
\hline Building Systems & Features of the eight typologies $(1-4 \mathrm{~A})$ \\
\hline Typology 1 & $\begin{array}{l}\text { Exterior Wall: Brick/block cavity wall. } \\
\text { Interior Wall: Cavity masonry unit with a sound barrier } \\
\text { Structures: Main beam - Hardwood post, secondary frame - glulam } \\
\text { Ground Floor: Timber raised floor with blown cellulose insulation } \\
\text { First Floor: I-section timber frame with board, finished with and resin floor finish } \\
\text { Windows: Double-glazed with an aluminium frame, filled with argon, U-value of } 1.55 \mathrm{~W} / \mathrm{m} 2 \mathrm{~K} \\
\text { Roofs: Wood framed slate roof } \\
\text { Ceiling: Steel grid, suspend gypsum ceiling } \\
\text { Column: Pressure treated sawn hardwood } \\
\text { HVAC: Gas fired boiler, steam from Central Power plant. } \\
\text { Electricity: } 100 \% \text { from external regional utility }\end{array}$ \\
\hline Typology $1 \mathrm{~A}$ & $\begin{array}{l}\text { Same as Typology } 1 \text { but electricity is from renewable sources, and the HVAC is from a } \\
\text { renewable source with a lower percentage of fossil fuel }\end{array}$ \\
\hline Typology 2 & $\begin{array}{l}\text { Exterior Wall: Cladded timber cavity wall filled with cellulose insulation. } \\
\text { Interior Wall: Timber cavity with cellulose insulation } \\
\text { Structures: Main beam - Hardwood post, secondary frame - glulam } \\
\text { Ground Floor: Timber raised floor with blown cellulose insulation } \\
\text { First Floor: Synthetic resin-finished timber frame and board } \\
\text { Windows: Timber-frame, double-glazed, argon-filled, U-value } 1.55 \mathrm{~W} / \mathrm{m} 2 \mathrm{~K} \\
\text { Roofs: EPDM covered flat roof with insulated timber plate } \\
\text { Ceiling: Steel grid, suspend gypsum ceiling } \\
\text { Column: Pressure treated sawn hardwood } \\
\text { HVAC: Gas fired boiler, steam from Central Power plant. } \\
\text { Electricity: } 100 \% \text { from external regional utility }\end{array}$ \\
\hline Typology $2 A$ & $\begin{array}{l}\text { Same as Typology } 2 \text { but the electricity is from renewable sources, and the HVAC is from a } \\
\text { renewable source with a lower percentage of fossil fuel }\end{array}$ \\
\hline Typology 3 & $\begin{array}{l}\text { Exterior Wall: ICF with Expanded Polystyrene. } \\
\text { Interior Wall:-Cavity CMU with polystyrene insulation. } \\
\text { Structures: Reinforced Concrete column structure } \\
\text { Ground Floor: Timber raised floor with blown cellulose insulation } \\
\text { First Floor: Precast concrete floor } \\
\text { Windows: Double-glazed with an aluminium frame, filled with argon, U-value of } 1.55 \mathrm{~W} / \mathrm{m} 2 \mathrm{~K} \\
\text { Roofs: a reinforced concrete flat roof having } 40 \% \text { GGBS/recycled aggregate } \\
\text { Ceiling: Steel grid, suspend gypsum ceiling } \\
\text { Column: Pressure treated sawn hardwood } \\
\text { HVAC: Gas fired boiler, steam from Central Power plant. } \\
\text { Electricity: } 100 \% \text { from external regional utility }\end{array}$ \\
\hline Typology $3 A$ & $\begin{array}{l}\text { Same as Typology } 3 \text { but the electricity is from renewable sources, and the HVAC is from a } \\
\text { renewable source with a lower percentage of fossil fuel }\end{array}$ \\
\hline Typology 4 & $\begin{array}{l}\text { Exterior Wall: Gypframe steel framed wall with polystyrene insulation. } \\
\text { Interior Wall: Timber/steel cavity with cellulose insulation. } \\
\text { Structures: Steel frame } \\
\text { Ground Floor: Steel plate raised on CMU, and finished with synthetic resin } \\
\text { First Floor: Gypframe steel flooring } \\
\text { Windows: Double-glazed with an aluminium frame, filled with argon, U-value of } 1.55 \mathrm{~W} / \mathrm{m} 2 \mathrm{~K} \\
\text { Roofs: Insulated steel plate flat roof covered with EPDM } \\
\text { Ceiling: Steel grid, suspend gypsum ceiling } \\
\text { Column: Pressure treated sawn hardwood } \\
\text { HVAC: Gas fired boiler, steam from Central Power plant. } \\
\text { Electricity: } 100 \% \text { from external regional utility }\end{array}$ \\
\hline Typology $4 A$ & $\begin{array}{l}\text { Same as Typology } 4 \text { but the electricity is from renewable sources, and the HVAC is from a } \\
\text { renewable source with a lower percentage of fossil fuel }\end{array}$ \\
\hline
\end{tabular}


Note:

Typology 1: Typical Brick/block building

Typology 2: Timber-framed structure

Typology 3: Insulated Concrete Forms building

Typology 4: Steel framed structure.

Typologies 1A, 1B, 1C \& 1D are energy efficient alternatives of the typologies $1,2,3 \& 4$ respectively.

Based on the output from the GBS, Table 3 presents the energy requirements for operating typologies 1, 2, 3 and 4.

Table 3: Energy requirements for building operation

\begin{tabular}{|c|c|c|c|c|}
\hline Building Typologies & $\begin{array}{l}\text { Annual Electric } \\
\text { Demand (KWh) }\end{array}$ & $\begin{array}{c}\text { Lifecycle } \\
\text { Demand }(K W h)\end{array}$ & $\begin{array}{l}\text { Annual Fuel } \\
\text { demand (MJ) }\end{array}$ & $\begin{array}{l}\text { Annual Fuel } \\
\text { demand }\left(m^{3}\right)\end{array}$ \\
\hline Brick/Block Building & 8,3420 & & \multirow{4}{*}{110,332} & \multirow{4}{*}{2,840} \\
\hline Timber framed building & 87,497 & & & \\
\hline Insulated Concrete Form & 83,102 & & & \\
\hline Steel Structure & 87,726 & & & \\
\hline
\end{tabular}

To test how energy use pattern determines the life cycle significance of embodied energy, four typologies $1 \mathrm{~A}$ to $4 \mathrm{~A}$ were modelled based on the use of renewable energy resources. Typologies $1 \mathrm{~A}$ to $4 \mathrm{~A}$ are the energy-efficient alternatives of typologies 1 to 4 respectively.

The GBS tool was used to calculate the amount of energy that could be generated by the building through the use of PV panel. Based on the energy generation capacity, a substitution was made for the fossil fuel based energy. The Energy use pattern for the building is presented in Figure 4. 

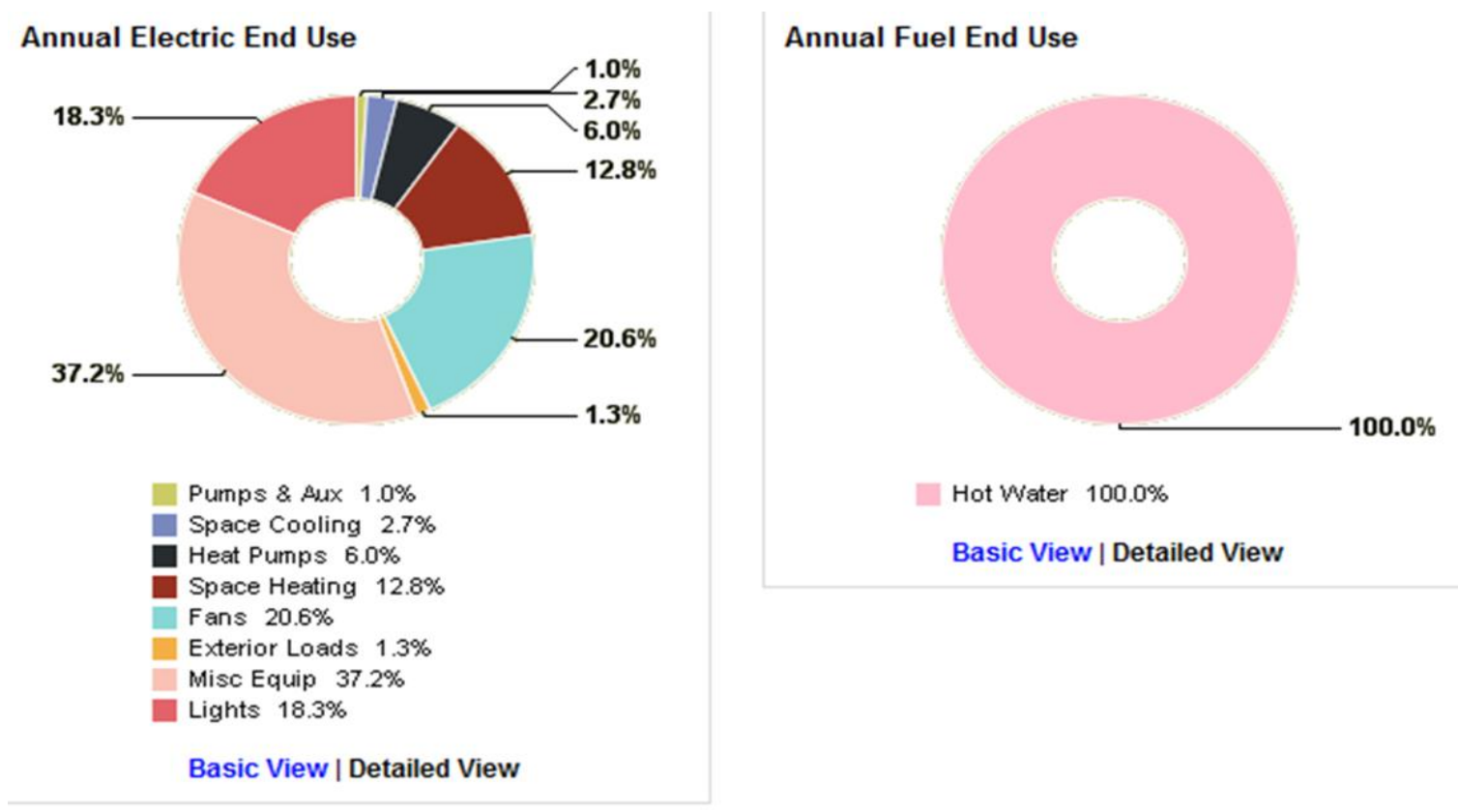

Figure 4: A typical simulated energy use pattern for an office building

It was assumed that the buildings' energy requirement needs for lighting, fans and miscellaneous equipment would be met through the renewable resources, while all its hot water needs would be met using a fuel-powered boiler.

For the buildings that are based on renewable technology, the embodied energy of the PV panel and solar water heater were calculated using data from existing literature. Based on the average figures from the earlier findings by Sherwani et al. (2010) and Zhong et al. (2011), the embodied impacts of PV panel was taken as $60 \mathrm{~g}$ of $\mathrm{CO}_{2} / \mathrm{Kwhe}$. As evidence suggests that about $97 \%$ of this emission is due to its manufacturing process (Fthenakis and Kim, 2011), 97\% of the calculated impact was added to the embodied impacts of the building, while the rest $3 \%$ was added to the end of life impacts.

\subsection{Findings}

Table 4 presents findings of the life cycle assessment of the eight typologies used for the study. The materials production, transportation and construction, are presented as embodied impacts while the impacts associated with the building use throughout 30 years are presented as operational impacts. End of life impacts is those associated with deconstruction, demolition, recycling and transportation of end of life waste. 
Table 4: Global Warming Potentials of the eight typologies

\begin{tabular}{|c|c|c|c|c|c|}
\hline \multicolumn{2}{|r|}{ Building Typologies } & $\begin{array}{c}\text { Embodied } \\
\text { Impacts }(K g C O 2)\end{array}$ & $\begin{array}{c}\text { Operational } \\
\text { Impacts }(\mathrm{Kg} C \mathrm{C} 2)\end{array}$ & $\begin{array}{c}\text { End of life } \\
\text { impacts }(\mathrm{KgCO} 2)\end{array}$ & $\begin{array}{c}\text { Total Impacts } \\
(\mathrm{KgCO} 2)\end{array}$ \\
\hline $\mathbf{1}$ & Brick/Block Building & $\begin{array}{l}5.08 \times 10^{5} \\
(22.3 \%)\end{array}$ & $\begin{array}{l}1.75 \times 10^{6} \\
(77.1 \%)\end{array}$ & $\begin{array}{l}1.47 \mathrm{X} 10^{4} \\
(0.60 \%)\end{array}$ & $2.27 \times 10^{6}$ \\
\hline $\mathbf{1 A}$ & $\begin{array}{c}\text { Low Energy } \\
\text { Alternative of Type } 1\end{array}$ & $\begin{array}{l}6.24 \times 10^{5} \\
(51.6 \%)\end{array}$ & $\begin{array}{c}5.69 \times 10^{5} \\
(47 \%)\end{array}$ & $\begin{array}{c}1.83 \times 10^{4} \\
(1.5 \%)\end{array}$ & $1.21 \times 10^{6}$ \\
\hline 2 & $\begin{array}{c}\text { Timber Framed } \\
\text { Structure }\end{array}$ & $\begin{array}{c}1.67 \times 10^{5} \\
(8.4 \%)\end{array}$ & $\begin{array}{c}1.83 \times 10^{6} \\
(91.4 \%)\end{array}$ & $\begin{array}{c}4.30 \times 10^{3} \\
(0.2 \%)\end{array}$ & $2.00 \times 10^{6}$ \\
\hline $2 \mathrm{~A}$ & $\begin{array}{c}\text { Low Energy } \\
\text { Alternative of Type } 2\end{array}$ & $\begin{array}{l}2.83 \times 10^{5} \\
(32.9 \%)\end{array}$ & $\begin{array}{c}5.70 \times 10^{5} \\
(66.2 \%)\end{array}$ & $\begin{array}{c}7.89 \times 10^{3} \\
(0.9 \%)\end{array}$ & $8.61 \times 10^{5}$ \\
\hline 3 & ICF Building & $\begin{array}{l}7.67 \times 10^{5} \\
(30.1 \%)\end{array}$ & $\begin{array}{c}1.75 \times 10^{6} \\
(68.9 \%)\end{array}$ & $\begin{array}{c}3.23 \times 10^{4} \\
(1.3 \%)\end{array}$ & $2.54 \times 10^{6}$ \\
\hline $\mathbf{3 A}$ & $\begin{array}{c}\text { Low Energy } \\
\text { Alternative of Type } 3\end{array}$ & $\begin{array}{l}8.83 \times 10^{5} \\
(59.7 \%)\end{array}$ & $\begin{array}{l}5.58 \times 10^{5} \\
(37.7 \%)\end{array}$ & $\begin{array}{c}3.58 \times 10^{4} \\
(2.4 \%)\end{array}$ & $1.48 \times 10^{6}$ \\
\hline 4 & $\begin{array}{c}\text { Steel Framed } \\
\text { Structure }\end{array}$ & $\begin{array}{l}4.10 \times 10^{5} \\
(18.3 \%)\end{array}$ & $\begin{array}{l}1.83 \times 10^{6} \\
(81.4 \%)\end{array}$ & $\begin{array}{c}6.20 \times 10^{3} \\
(0.3 \%)\end{array}$ & $2.25 \times 10^{6}$ \\
\hline $4 \mathrm{~A}$ & $\begin{array}{c}\text { Low Energy } \\
\text { Alternative of Type } 4\end{array}$ & $\begin{array}{l}5.26 \times 10^{5} \\
(47.5 \%)\end{array}$ & $\begin{array}{l}5.71 \times 10^{5} \\
(51.5 \%)\end{array}$ & $\begin{array}{l}9.80 \times 10^{3} \\
(0.9 \%)\end{array}$ & $1.11 \times 10^{6}$ \\
\hline
\end{tabular}

\subsection{Discussion}

This section discusses the findings of the study in line with the goals of the study. The varying significance of embodied energy with varying building materials specification and energy use patterns are discussed.

\subsection{Materials specification and embodied energy}

Changes in materials specification have significant impacts on the distribution of life cycle impacts of the buildings. Figure 5 compares the life cycle impacts of the four main typologies. 


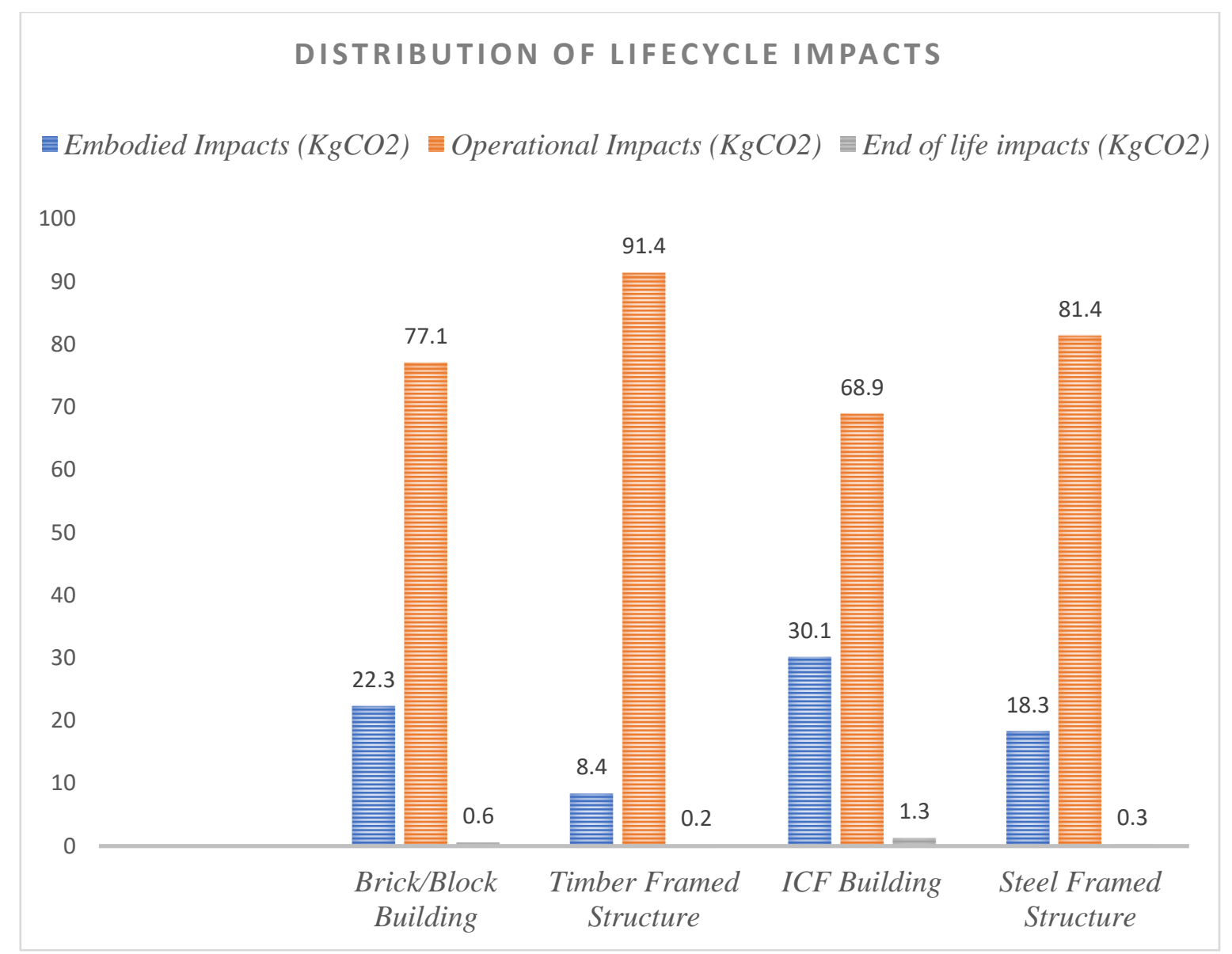

Figure 5: Varying distribution of life cycle impacts based on materials specifications

As shown in Figure 5, the operational impacts of all the building typologies have the highest proportion of their life cycle impacts, and it ranges from $68 \%$ to $91 \%$ for buildings that are operated using conventional fossil fuel-based electricity and gas system. This finding justifies the current stand of most sustainable design appraisal system such as BREEAM and LEED that give significant attention to the operational stage of the building lifecycle. However, the embodied carbon of the buildings accounts for a range of $8.4 \%$ to $22.3 \%$ over the entire life cycle of the buildings. This finding aligns with the previous review of 73 case studies across 73 countries, which suggests that embodied energy could range between 10 and $20 \%$ of whole life impacts of buildings (Ramesh et al., 2010).

Although the embodied energy of conventional fossil fuel powered buildings are found to be significantly lower than the operational energy, it does not justify the meaning attached to the concept of "Zero Carbon" building, which gives a complete disregard to the embodied energy despite its tendency of contributing up to $20 \%$ of life cycle impacts in some cases. Generically, a building is considered to be "zero carbon" if it has no net carbon emissions arising from the 
building operation during its use stage (Ibn-Mohammed et al., 2013). This, therefore, suggests that irrespective of the environmental impacts of the materials used for its construction, a highly polluting building could be termed as being carbon neutral.

A significant trend in the proportion of the embodied energy of the buildings is that heavily walled buildings such as those constructed with concrete and bricks have more embodied energy than those constructed of a lightweight framed structure such as timber and steel. This confirms that materials with higher thermal mass would not only reduce operational energy, they significantly contribute to the embodied impacts of the buildings (Hacker et al., 2008). It is therefore essential that balance is made between the benefits of higher thermal mass for operational efficiency and its high embodied energy. For instance, embodied impacts of the building constructed with Insulated Concrete Form is $22.3 \%$, while that of the timber frame structure is $8.4 \%$. While the embodied impacts increased with building thermal mass, their operational impacts reduced as shown in Table 4.

Nonetheless, the overall lifecycle impacts of buildings increase with the increased thermal mass of the construction materials. This finding suggests that the difference in percentage impact of embodied energy is not necessarily because of geographic location and climate as earlier suggested by Nebel et al. (2011), but due to variation in materials and construction techniques. It, therefore, confirms the varying significance of embodied energy as the construction materials and methods change.

Despite this significance, there has been less consideration of embodied energy from a policy perspective (Hernandez and Kenny, 2010). A potential way of addressing this is the use of environmental rating for different construction materials and method (Anderson et al., 2009), as well as a development of whole life assessment methodology instead of the usual ways of giving sole importance to the operational impacts of buildings (Ajayi et al., 2015). Since the embodied energy could contribute up to one-fifth of the whole life impacts, it is crucial that sustainable design appraisal systems such as BREEAM, as well as building regulations, are used for engendering the use of low impact materials and construction techniques. 


\subsection{Energy use pattern and the changing significance of embodied energy}

Due to increasing awareness of the environmental impacts of buildings, there has been a significant uptake of renewable energy resources and energy efficient building construction (Twidell and Weir, 2015). As such, various renewable technologies, including solar PV panel, ground and air source heat pump, solar water heater and biomass, among others, have been widely used on building scales (Pearce and Ahn, 2013). The use of these renewable systems has impacts on both operational and embodied impacts of buildings. Figure 6 shows the distribution of life cycle impacts of energy efficient alternatives to building typologies 1 to 4 (1A to 4A) that were used for the study.

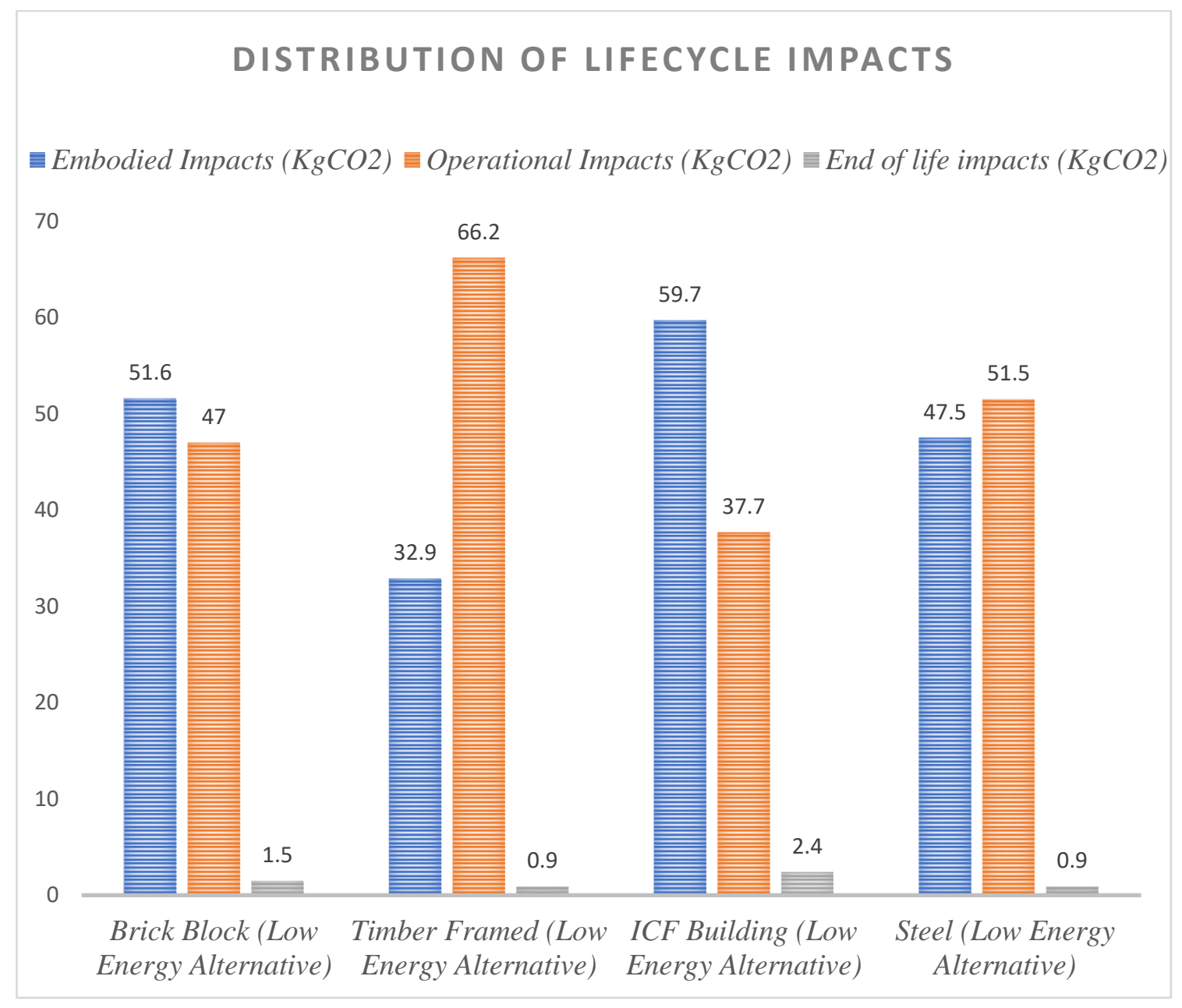

Figure 6: Varying distribution of lifecycle impacts of energy-efficient building typologies

Unlike the conventional buildings presented in Figure 5, increasing use of renewable energy resources suggests that the embodied impact is becoming more important or, at least, as equally important as the operational energy of buildings. As shown in Figure 6, embodied impacts become highly significant as buildings reduce its reliance on fossil fuel-based energy resources. 
The embodied energy of the building typologies ranges between $32.9 \%$ and $59.7 \%$ of the whole life impacts. This indicates that as people adopt renewable energy resources, whether as a result of legislative or economic drivers, there is an increasing need to address the environmental impacts associated with the embodied energy of buildings. This is especially important as the use of renewable energy resources is expected to grow into the future (Devabhaktuni et al., 2013).

For low energy buildings, the proportion of life cycle impacts contributes by the embodied carbon of building was reported to be within the range of $40-60 \%$ (Thormark, 2007). Similarly, Huberman and Pearlmutter (2008) suggest that the embodied energy of climate responsive buildings could be up to $60 \%$ over a lifespan of 50 years. These figures align with the findings of this study, which puts the embodied carbon of low energy buildings within the range of $33-60 \%$. Thus, the more the adoption of renewable energy technologies and low impact buildings, the more the need to increase the focus on the embodied energy of buildings. As earlier suggested, a potential method of engendering designers' awareness and consideration of embodied impacts of buildings is by increasing the proportional weight and significance attached to the embodied impacts of buildings, especially in sustainable design appraisal systems and building regulations.

\subsection{Increasing significance of embodied energy}

Embodied impacts of building vary across the whole life of buildings, and it is mostly influenced by both the nature of materials and the energy use patterns of the buildings. Figure 7 compares the proportion of the embodied and operational energy for the eight typologies used for this study. 


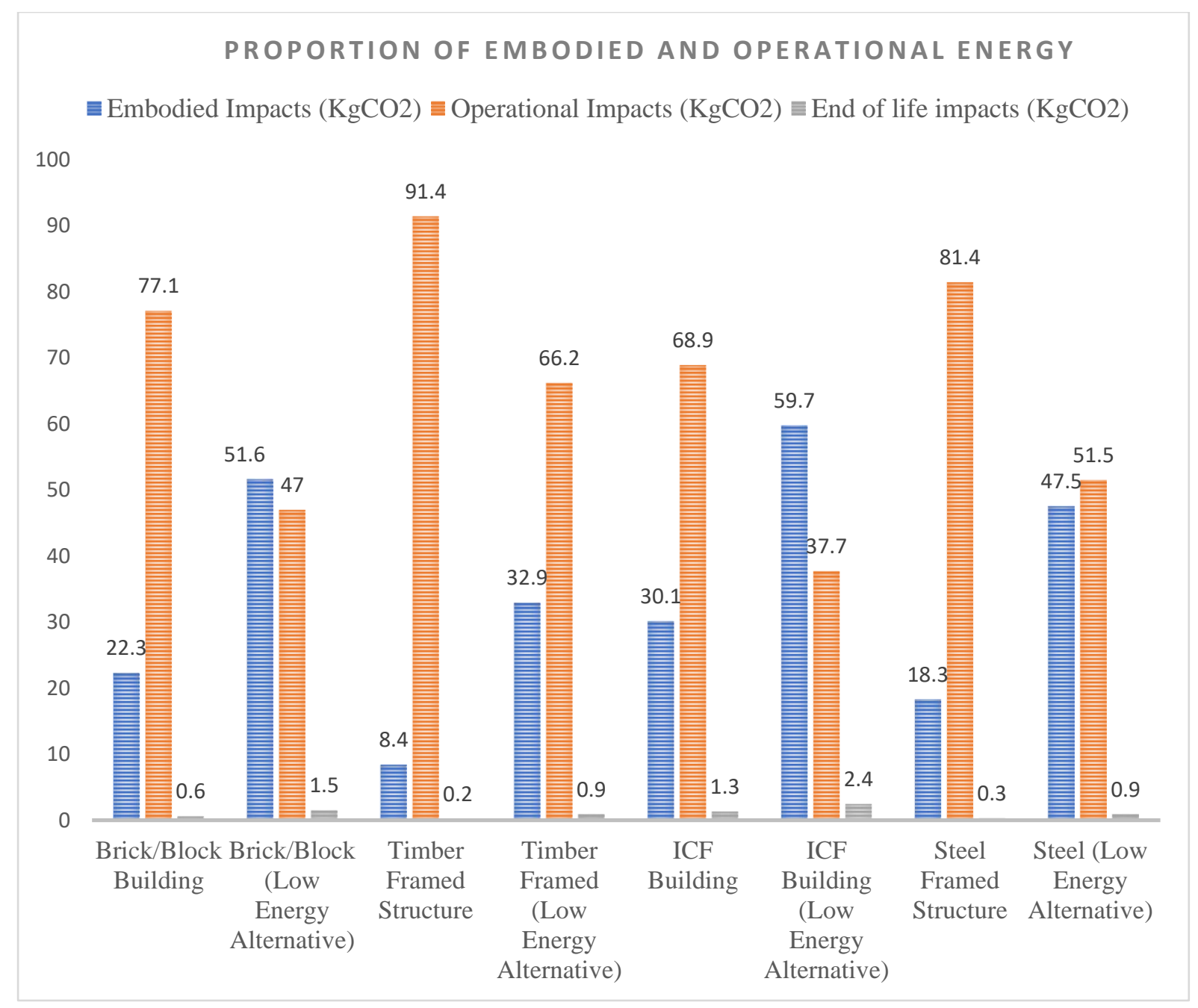

Figure 7: Proportional distribution of carbon emission across the building lifecycle

Figure 7 shows that depending on construction materials and energy use patterns, embodied energy of a building could contribute between $8-60 \%$ of its lifecycle impacts. The result also shows that timber-framed building has the least embodied energy irrespective of whether it is operated by fossil fuel-based energy resources or renewable energy. However, the timberframed building with renewable energy has a higher proportion of operational energy than other building typologies. Although the total life-cycle emission by the timber-framed building is significantly less than that of other building typologies, the finding points out to the likelihood of increasing embodied energy as buildings become energy efficient during their operational stage. This is mainly as passive buildings usually require more materials, either in terms of insulation and thickness of external elements or embodied energy of renewable resources with which the buildings are operated (Sadineni et al., 2011). 


\subsection{Conclusion and Implication for Practice and Policy Making}

This section summarises the findings of the study. The implications of the study for practice, policy-making and future research directions are also presented in the section.

\subsection{Summary of the Study and Findings}

This study investigates the changing significance of embodied carbon over the entire life cycle of whole buildings. Using LCA methodology, the impacts of materials specification and renewable energy resources on embodied and operational impacts were investigated. A case study of an office building was modelled with Revit, and sensitivity analyses of the modelled building were performed by varying the material specification and energy use pattern for other seven typologies.

The study suggests that notwithstanding the huge impacts of the operational stage on life-cycle carbon of fossil fuel-based buildings, embodied impacts could vary between 8.4 and $22.3 \%$. A key determinant of the proportional impacts of the embodied energy is the nature of materials used for building construction. Buildings constructed of materials with high thermal mass such as concrete and brick are found to reduce operational energy, but in turn, increase the embodied impacts over the entire lifecycle. Timber and steel framed buildings, on the other hand, embodied less carbon with a less significant increase in their operational impacts. The increase in the embodied energy outweighs the gain made from operational energy in both cases, especially as the timber and steel frame buildings are provided with adequate insulation materials. This, therefore, suggests the needs for reduced embodied energy as a means of reducing whole life environmental impacts of buildings.

Similarly, the study suggests an increasing significance of the embodied impacts of buildings as they become energy efficient during their operational stage. Buildings that are based on renewable energy resources are likely to embody between eight and $60 \%$ of their lifecycle impacts, while those that are based on fossil fuel resources such as electricity are gas is found to embody lesser proportion of carbon. This confirms that the current trend of increasing use of renewable energy resources would result in a high proportion of embodied impacts over the entire lifecycle of buildings. 


\subsection{Implications for Practice and Policy Making}

As the study confirms the varying significance of embodied energy with changes in construction materials and methods, it implies the needs for policy measures that consider the environmental impacts of buildings beyond the operational stage. A possible means of driving an effective trade-off between the operational and embody impacts is to ensure that whole life assessment methodology is adopted instead of the usual ways of giving sole importance to the operational impacts of buildings. Assigning environmental weights to different construction materials and method is a potential way of driving the use of low impacts construction materials that embody low carbon.

Sustainability of the built environment has been primarily driven by building regulations and sustainable design appraisal tools. These sets of building appraisal tools have been used to drive energy efficiency. Increasing consideration of embodied impacts of building materials is therefore expected of sustainable design appraisal systems such as BREEAM, as well as building regulations, as they remain the essential tools for driving sustainability in the built environment. This is especially important as a recent analysis by Ajayi et al. (2019) suggests that sustainable design appraisal tools have not been doing enough to drive the required reduction in embodied energy of buildings.

The current practice of sustainable design among designers has been largely based on the energy efficiency of buildings during the operational stage of its life cycle. Widely used software tools such as ECOTECT, GBS and DesignBuilder, among others, allow the design to meet performance targets at the early design stage. However, these sets of software tools mainly target energy, daylighting, heating and cooling requirements without necessarily considering the embodied impacts of construction materials. Consequent to the finding of this study, there is a need to shift the focus from operational impacts to embodied impacts, especially as legislative provisions, awareness of environmental and economic benefits have already engendered an increasing use of renewable energy resources for building operation. Such legislative and policy measures are, therefore, required for driving the use of low impact construction materials to enhance real and thorough sustainability of the built environment. It is, therefore, vital that whole life impacts are considered when evaluating the environmental impacts of buildings. 
Consequently, designers and other project team members are expected to consider measures to reduce the embodied energy of buildings. Such measures include a selection of material with low embodied energy, such as timber in place of concrete as demonstrated in this study. Other measures include selection of secondary materials (Oyedele et al., 2014), materials optimisation and minimisation of waste generation (Thormark, 2002; Ajayi et al., 2017), design for deconstruction and materials recovery (Akinade et al., 2017), and increasing the recycling potential of buildings (Thormark, 2006), among others.

\subsection{The implication for Future Academic Research}

Although a building use type is unlikely to affect its embodied energy, it should nonetheless be noted that a case study of office block has been used for the study and the findings should be interpreted as such. Other building types such as residential, education, retail and industrial buildings could be evaluated by other studies. Since the life cycle assessment has been estimated over a period of 30 years, materials replacement has not been considered in the study. Further research could consider longer life cycle duration with the inclusion of the embodied impacts of materials replacement and building refurbishment process. Notwithstanding that the Green Building Studio and ATHENA impacts estimator have been widely approved and used for building simulation and LCA, it is important to note that the accuracy of the simulated results largely depends on the tools.

Several software tools for simulating the operational performance of buildings at early design stage have been developed. Some of the building design appraisal have been fully integrated into design tools, or at least compatible with the design tools. The integration and compatibility of such tools have enhanced operational performance of buildings, as designers can evaluate the performance of various design options at the early design stage. However, whole life building simulations have been hindered by the lack of fully integrated holistic LCA tools. Current practices of LCA has been based on time-consuming computational analysis or a combination of various tools. For instance, while ATHENA Impact Estimator and Ecoinvent can estimate the inventory of materials, they are unable to estimate the whole life impacts of building typologies. Future research could, therefore, consider the development of software tools that can evaluate the whole life impacts of various design options. Integration of such tool with BIM-based design tools would enhance its functional performance, thereby encouraging whole life analysis and trading-off between embodied and operational impacts at the early design stage. 


\section{References}

Adalberth, K., 1997. Energy use during the life cycle of buildings: a method. Building and Environment, 32(4), pp.317-320.

Ajayi, S.O., Oyedele, L.O. and Dauda, J.A., 2019. Dynamic relationship between embodied and operational impacts of buildings: An evaluation of sustainable design appraisal tools. World Journal of Science, Technology and Sustainable Development, https://doi.org/10.1108/WJSTSD-05-2018-0048

Ajayi, S.O., Oyedele, L.O., Akinade, O.O., Bilal, M., Alaka, H.A. and Owolabi, H.A., 2017. Optimising material procurement for construction waste minimization: An exploration of success factors. Sustainable Materials and Technologies, 11, pp.38-46.

Ajayi, S.O., Oyedele, L.O., Ceranic, B., Gallanagh, M. and Kadiri, K.O., 2015. Life cycle environmental performance of material specification: a BIM-enhanced comparative assessment. International Journal of Sustainable Building Technology and Urban Development, 6(1), pp.14-24.

Ajayi, S.O., Oyedele, L.O., Jaiyeoba, B., Kadiri, K. and David, S.A., 2016. Are sustainable buildings healthy? An investigation of lifecycle relationship between building sustainability and its environmental health impacts. World Journal of Science, Technology and Sustainable Development, 13(3), pp.190-204.

Akinade, O.O., Oyedele, L.O., Ajayi, S.O., Bilal, M., Alaka, H.A., Owolabi, H.A., Bello, S.A., Jaiyeoba, B.E. and Kadiri, K.O., 2017. Design for Deconstruction (DfD): Critical success factors for diverting end-of-life waste from landfills. Waste management, 60 , pp.3-13.

Anderson, J. and Shiers, D. and Steele, K., 2009. Green guide to specification: An environmental profiling system for building materials and components, 4th edition. Chichester: John Wiley \& Sons.

ATHENA, 2013. "Athena Impact Estimator for Buildings: V 4.2 Software and Database Overview". Canada: Athena.

Azhar, S., Carlton, W.A., Olsen, D. and Ahmad, I., 2011. Building information modeling for sustainable design and LEED® rating analysis. Automation in construction, 20(2), pp.217-224. 
Baek, C., Park, S.H., Suzuki, M. and Lee, S.H., 2013. Life cycle carbon dioxide assessment tool for buildings in the schematic design phase. Energy and Buildings, 61, pp.275-287.

Basbagill, J., Flager, F., Lepech, M. and Fischer, M., 2013. Application of life-cycle assessment to early stage building design for reduced embodied environmental impacts. Building and Environment, 60, pp.81-92.

Bribián, I.Z., Usón, A.A. and Scarpellini, S., 2009. Life cycle assessment in buildings: Stateof-the-art and simplified LCA methodology as a complement for building certification. Building and Environment, 44(12), pp.2510-2520.

Ceranic, B., 2013. Sustainable design analysis and BIM integration. Emmitt, S., 2013. Architectural technology: research and practice. John Wiley \& Sons., pp.89-119.

Chang, Y., Ries, R.J. and Wang, Y., 2011. The quantification of the embodied impacts of construction projects on energy, environment, and society based on I-O LCA. Energy Policy, 39(10), pp.6321-6330.

Cole, R.J., 2005. Building environmental assessment methods: redefining intentions and roles. Building Research \& Information, 33(5), pp.455-467.

Devabhaktuni, V., Alam, M., Depuru, S.S.S.R., Green, R.C., Nims, D. and Near, C., 2013. Solar energy: Trends and enabling technologies. Renewable and Sustainable Energy Reviews, 19, pp.555-564.

Ding, G.K., 2008. Sustainable construction-The role of environmental assessment tools. Journal of environmental management, 86(3), pp.451-464.

ENSLIC, (2010); ENSLIC BUILDING: Energy Saving through Promotion of Life Cycle Assessment in Buildings. Europe: Intelligent Energy and ENSLIC.

Fay, R., Treloar, G. and Iyer-Raniga, U., 2000. Life-cycle energy analysis of buildings: a case study. Building Research \& Information, 28(1), pp.31-41.

Fthenakis, V.M. and Kim, H.C., 2011. Photovoltaics: Life-cycle analyses. Solar Energy, 85(8), pp.1609-1628.

Ghattas, R., Gregory, J., Olivetti, E., Greene, S. and Hub, C.S., 2013. Life cycle Assessment for residential buildings: A literature review and gap analysis. Concrete Sustainability Hub Massachusetts Institute of Technology.

Hacker, J.N., De Saulles, T.P., Minson, A.J. and Holmes, M.J., 2008. Embodied and operational carbon dioxide emissions from housing: a case study on the effects of thermal mass and climate change. Energy and Buildings, 40(3), pp.375-384.

Hamilton, L., Edwards, S., Aizlewood, C., Shiers, D., Thistlethwaite, P., and Steele, K., 2007. Creating environmental weightings for construction products. Bracknell: BRE Press 
Hamilton-MacLaren, F., Loveday, D.L. and Mourshed, M., 2009. The calculation of embodied energy in new build UK housing. In: Dainty, A.R.J. (ed). Proceedings of the 25th Annual ARCOM Conference, Nottingham, September 2009. Reading: ARCOM.

Hammond, G. P. and Jones, C. I., 2008. Embodied energy and carbon in construction materials. Proceedings of the Institution of Civil Engineers - Energy, 161 (2), pp. 8798.

Hernandez, P. and Kenny, P., 2010. From net energy to zero energy buildings: Defining life cycle zero energy buildings (LC-ZEB). Energy and Buildings, 42(6), pp.815-821.

Huberman, N. and Pearlmutter, D., 2008. A life-cycle energy analysis of building materials in the Negev desert. Energy and Buildings, 40(5), pp.837-848.

Ibn-Mohammed, T., Greenough, R., Taylor, S., Ozawa-Meida, L. and Acquaye, A., 2013. Operational vs. embodied emissions in buildings-A review of current trends. Energy and Buildings, 66, pp.232-245.

Kajikawa, Y., Inoue, T. and Goh, T.N., 2011. Analysis of building environment assessment frameworks and their implications for sustainability indicators. Sustainability Science, 6(2), pp.233-246.

Khasreen, M.M., Banfill, P.F. and Menzies, G.F., 2009. Life-cycle assessment and the environmental impact of buildings: a review. Sustainability, 1(3), pp.674-701.

Kofoworola, O.F. and Gheewala, S.H., 2009. Life cycle energy assessment of a typical office building in Thailand. Energy and Buildings, 41(10), pp.1076-1083.

Kubba, S., 2012. Handbook of green building design and construction: LEED, BREEAM, and Green Globes. Butterworth-Heinemann.

Li, Z., 2006. A new life cycle impact assessment approach for buildings. Building and Environment, 41(10), pp.1414-1422.

Mithraratne, N. and Vale, B., 2004. Life cycle analysis model for New Zealand houses. Building and Environment, 39(4), pp.483-492.

Moncaster, A.M. and Song, J.Y., 2012. A comparative review of existing data and methodologies for calculating embodied energy and carbon of buildings. International Journal of Sustainable Building Technology and Urban Development, 3(1), pp.26-36.

Nebel, B., Alcorn, A. and Wittstock, B., 2011. Life cycle assessment: adopting and adapting overseas LCA data and methodologies for building materials in New Zealand. Ministry of Agriculture and Forestry. 
Nizam, R.S., Zhang, C. and Tian, L., 2018. A BIM based tool for assessing embodied energy for buildings. Energy and Buildings, 170, pp.1-14.

Optis, M. and Wild, P., 2010. Inadequate documentation in published life cycle energy reports on buildings. The International Journal of Life Cycle Assessment, 15(7), pp.644-651.

Ortiz, O., Castells, F. and Sonnemann, G., 2009. Sustainability in the construction industry: A review of recent developments based on LCA. Construction and Building Materials, 23(1), pp.28-39.

Oyedele, L.O., Ajayi, S.O. and Kadiri, K.O., 2014. Use of recycled products in UK construction industry: An empirical investigation into critical impediments and strategies for improvement. Resources, Conservation and Recycling, 93, pp.23-31.

Pearce, A. and Ahn, Y.H., 2013. Sustainable buildings and infrastructure: paths to the future. Routledge

Poveda, C.A. and Lipsett, M.G., 2011. A review of sustainability assessment and sustainability/environmental rating systems and credit weighting tools. Journal of Sustainable Development, 4(6), p.36.

Ramesh, T., Prakash, R. and Shukla, K.K., 2010. Life cycle energy analysis of buildings: An overview. Energy and buildings, 42(10), pp.1592-1600.

Ramesh, T., Prakash, R. and Shukla, K.K., 2012. Life cycle energy analysis of a residential building with different envelopes and climates in Indian context. Applied Energy, 89(1), pp.193-202.

Rossi, B., Marique, A.F., Glaumann, M. and Reiter, S., 2012. Life-cycle assessment of residential buildings in three different European locations, basic tool. Building and Environment, 51, pp.395-401.

Sadineni, S.B., Madala, S. and Boehm, R.F., 2011. Passive building energy savings: A review of building envelope components. Renewable and Sustainable Energy Reviews, 15(8), pp.3617-3631.

Sartori, I. and Hestnes, A.G., 2007. Energy use in the life cycle of conventional and lowenergy buildings: A review article. Energy and buildings, 39(3), pp.249-257.

Säynäjoki, A., Heinonen, J. and Junnila, S., 2012. A scenario analysis of the life cycle greenhouse gas emissions of a new residential area. Environmental Research Letters, 7(3), p.034037. 
Scheuer, C., Keoleian, G.A. and Reppe, P., 2003. Life cycle energy and environmental performance of a new university building: modeling challenges and design implications. Energy and buildings, 35(10), pp.1049-1064.

Sharma, A., Saxena, A., Sethi, M. and Shree, V., 2011. Life cycle assessment of buildings: a review. Renewable and Sustainable Energy Reviews, 15(1), pp.871-875.

Sherwani, A.F. and Usmani, J.A., 2010. Life cycle assessment of solar PV based electricity generation systems: A review. Renewable and Sustainable Energy Reviews, 14(1), pp.540-544.

Soares, N., Bastos, J., Pereira, L.D., Soares, A., Amaral, A.R., Asadi, E., Rodrigues, E., Lamas, F.B., Monteiro, H., Lopes, M.A.R. and Gaspar, A.R., 2017. A review on current advances in the energy and environmental performance of buildings towards a more sustainable built environment. Renewable and Sustainable Energy Reviews, 77, pp.845-860.

Tavares, V., Lacerda, N. and Freire, F., 2019. Embodied energy and greenhouse gas emissions analysis of a prefabricated modular house: The "Moby" case study. Journal of Cleaner Production, 212, pp.1044-1053.

Thormark, C., 2002. A low energy building in a life cycle-its embodied energy, energy need for operation and recycling potential. Building and environment, 37(4), pp.429-435.

Thormark, C., 2006. The effect of material choice on the total energy need and recycling potential of a building. Building and Environment, 41(8), pp.1019-1026.

Thormark, C., 2007. Energy and resources, material choice and recycling potential in low energy buildings. In CIB Conference, $S B$ (Vol. 7).

Twidell, J. and Weir, T., 2015. Renewable energy resources. Routledge.

Utama, N.A., Mclellan, B.C., Gheewala, S.H. and Ishihara, K.N., 2012. Embodied impacts of traditional clay versus modern concrete houses in a tropical regime. Building and Environment, 57, pp.362-369.

Van Ooteghem, K. and Xu, L., 2012. The life-cycle assessment of a single-storey retail building in Canada. Building and Environment, 49, pp.212-226.

Wang, E., Shen, Z. and Barryman, C., 2011. A building LCA case study using Autodesk Ecotect and BIM model.

Webster, M.D., 2004. Relevance of structural engineers to sustainable design of buildings. Structural engineering international, 14(3), pp.181-185. 
Zhan, J., Liu, W., Wu, F., Li, Z. and Wang, C., 2018. Life cycle energy consumption and greenhouse gas emissions of urban residential buildings in Guangzhou city. Journal of Cleaner Production.

Zhong, Z.W., Song, B. and Loh, P.E., 2011. LCAs of a polycrystalline photovoltaic module and a wind turbine. Renewable Energy, 36(8), pp.2227-2237. 